\begin{tabular}{|l|l|l||}
\hline \multicolumn{2}{|c|}{ PublisherInfo } \\
\hline \hline PublisherName & $:$ & BioMed Central \\
\hline \hline PublisherLocation & $:$ & London \\
\hline \hline PublisherImprintName & $:$ & BioMed Central \\
\hline \hline
\end{tabular}

\title{
Virology pioneer dies
}

\begin{tabular}{|l|c|l||}
\hline \multicolumn{2}{|c|}{ ArticleInfo } \\
\hline \hline ArticleID & $:$ & 4698 \\
\hline \hline ArticleDOI & $:$ & $10.1186 /$ gb-spotlight-20030213-01 \\
\hline \hline ArticleCitationID & $:$ & spotlight-20030213-01 \\
\hline \hline ArticleSequenceNumber & $:$ & 50 \\
\hline \hline ArticleCategory & $:$ & Research news \\
\hline ArticleFirstPage & $:$ & 1 \\
\hline \hline ArticleLastPage & $:$ & 3 \\
\hline \hline & & RegistrationDate : 2003-2-13 \\
\hline ArticleHistory & $:$ & OnlineDate \\
\hline \hline ArticleCopyright & $:$ & BioMed Central Ltd2003-2-13 \\
\hline \hline ArticleGrants & $:$ & \\
\hline \hline ArticleContext & $:$ & 130594411 \\
\hline \hline
\end{tabular}




\section{Emma Hitt}

Email: emma@emmasciencewriter.com

Harold S. Ginsberg, a microbiologist who contributed fundamental research findings to the fields of virology and infectious disease, died in Woods Hole, Massachusetts from pneumonia on February 2nd at the age of 85 .

Ginsberg is perhaps best known for characterizing adenoviruses, work he began in the late 1950's at what is now Case Western Reserve University. He eventually described their structure, replication and their role in causing infections such as atypical pneumonia, pharyngitis and acute respiratory disease.

Ginsberg was born in Daytona Beach, Florida and received his undergraduate degree from Duke and his medical degree from Tulane University. After serving in the military, he became an associate professor at the Rockefeller Institute (now Rockefeller University). Then in 1951, he began teaching at Western Reserve University. Nine years later, he went to chair the microbiology department at the University of Pennsylvania.

From 1973 to 1985, Ginsberg chaired Columbia University Medical School's microbiology department, and towards the end of his career, he held an emeritus position at the National Institute of Allergy and Infectious Diseases (NIAID).

While Ginsberg was working at NIAID, he collaborated with George A. Prince in the Laboratory of Infectious Diseases to develop an animal model of adenovirus infection in the cotton rat.

Prince, who went on to co-found a company called Virion Systems, in Rockville, Maryland, for which Ginsberg served as a scientific advisor, notes that "his most important contribution came from defining the in vivocontribution of viral immunoregulatory genes."

Specifically, Ginsberg and colleagues found that the genes in the E3 region of the adenovirus downregulate the host inflammatory response, thus making virus-infected cells more difficult targets and prolonging the course of infection, Prince told us. The finding had implications for the safety of gene therapy, in which the E3 region was deleted to make way for the therapeutic gene - often to the detriment of the patient.

Late, at NIAID, Ginsberg began to study the simian immunodeficiency virus to learn how infection progresses once a host becomes infected.

Ginsberg's first major contribution took place while he was stationed at an Army hospital in England during World War II. He noticed a high incidence of hepatitis B in wounded soldiers receiving blood transfusions and determined that the pooled blood was the source of these infections. For this, the US Army awarded him the Legion of Merit Award in 1945.

Saul J. Silverstein, now chair of microbiology at Columbia, whom Ginsberg recruited, describes the finding as a "remarkable accomplishment" in an era when hepatitis viruses had not yet been isolated. 
Silverstein remembers Ginsberg as having an extremely inquisitive mind. "Later on, (Ginsberg) suffered from Alzheimer's disease," Silverstein told us, "but he was still very quick-witted, even in his later years at the NIAID - he would ask the questions that got right to the heart of the matter."

Prince remembers his former colleague as a joy to work with. "As his health failed, he never forgot to give generous thanks to all who assisted him," said Prince. "We loved him, and in today's scientific world of outsized egos he will remain our ideal."

Ginsberg was a member of the National Academy of Sciences and received numerous scientific awards. He published more than 200 scientific papers and contributed to several books, including the widely-used textbook, Microbiology(Lippincott, Williams \& Wilkins).

He lived in Woods Hole and in Washington, DC with his wife of 53 years, Marion Reibstein Ginsberg. He is also survived by four children; Benjamin, Peter, Ann and Jane; eight grandchildren and one brother, Joseph.

\section{References}

1. Case Western Reserve University, [http://www.cwru.edu/]

2. Rockefeller Institute for Medical Research, [http://clinfo.rockefeller.edu/hospdes.htm]

3. University of Pennsylvania, [http://www.upenn.edu/]

4. Columbia University Health Sciences, [http://cpmcnet.columbia.edu/index.html]

5. National Institute of Allergy and Infectious Diseases, [http://www.niaid.nih.gov/default.htm]

6. National Academy of Sciences, [http://www4.nationalacademies.org/nas/nashome.nsf]

This PDF file was created after publication. 